\title{
THE COMPARATIVE CHARACTERISTICS OF ILMENITE FROM THE KIMBERLITE PROVINCES OF THE USSR.
}

\author{
Garanin, V.K., Kudrjavtseva, G.P. and Laverova, T.N.
}

Geological Department of Moscow State University, 119899, Lenin's Hills, Moscow, USSR.

Ilmenite is a widely spreal mineral in the kimberlite pipes of the Jakutian liamond bearing province. It occurs as inclusions in the diamonds, impregrations in the ground mass of kimberlite, in senoliths of the mantle rocks (peridotites, pyroxenites, eclogites), including the diamond bearing ones. It is the accessory mineral of the kimberlite rocks. Two genetic sources of this mineral are discovered in the Jakutian kimberlites: a) ilmenite - the product of disintegration of the abyssal rocks of ultrabasic and basic composition and metasomatised rocks; b) ilmenite from the ground mass of kimberlites.

Ilmenite from the deep rocks is characterized by the considerable range of the composition. Several stages of the ilmenite rock formation are established. The genesis of this mineral is connected with the evolution of ragnesian-ferrous mantle melt, enriched by titanium. Crystallization differentiation in combination with liquation leads to the crystallization of the mottled series of the ilmenite rocks: peridotites, pyroxenites and eclogites. The earliest of them are crystallised in the diamond stability field.

Ilmenite from the ultrabasic rocks is characterized by the high content of magresium (more than 6 wt. $\frac{\circ}{6}$ MgO), increased of aluminiurn $\left(0.4\right.$ wt. $\mathrm{A}_{\mathrm{r}} \mathrm{A} \mathrm{O} \mathrm{x}$ ) and chromium (more than 0.4 wt.o $\mathrm{Cr} \mathrm{O}_{\mathrm{a}}$ to $10 \mathrm{wt} . \%$ ) ; from eclugites - low content of magnesium (less than 4 wt.o $\mathrm{MgO}$ ), aluminium ( 0.3 wt. $\mathrm{o}$. $\mathrm{Al} \mathrm{O}_{\mathrm{z}}$ ), chromium $(0.2$ wt. $\% \mathrm{Cr}=\mathrm{O}=\mathrm{s})$ and somewhist increaserl content of manganese (more than 0.5 wt. $8 \mathrm{MnO}$ ). The trend of the ilmenite rocks evolution is finished by the formation of original high-ferrous garnet-ilmenite intergrowths; the ilmenite in them is characterized by high content of hematite minal ( $>20$ mol.g Fe...

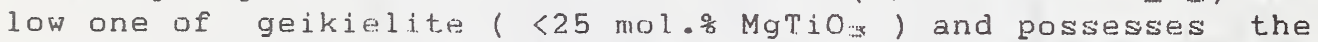
ferrimagnetic properties at room temperature. The similar ilmenite is widely spread in the central part of Jakutian province (Malo-Botuobinsknje field), the bodies there are characterized by the highest diamond bearing. In this case, the presence of ilmenite influences consilierably the magnetization over the kimberlite pipes of this region. The regular change of the composition of ilmenite from the ultrabasic rocks, is observed in the nothern direction during the transition from the central field to the periphery of the province: its contents of magnesium and chromium in the ilmenite are increased and the degree of the change of rocks ass a result of the occurence of the processses of the mantle metasomatism is increased.

In some kimberlite bodies, in ilmenite nodules, the lame1.s of decomposition of the solid solution, represented by the chrome spinels of the varying composition are widely observed. The regular connection between the wide spreading of the similar ilmenite and decrease of the kimberlite bodies diamond bearing is discovered. The mineralogical criterion of the evaluation of the kimberlite bodies diamond bearing has been developed on the basis on the phase heterogenelty of 1 imenite.

The ilmenite composition from the ground mass of kimberlites is being regularly changed from high magnesian (MgO) 
5 wt.o f) of chrome ilmenite in the productive pipes and low magnesian (Mgo < 5 wt. $\%$ ) manganese in poor productive pipes. The differences in the ilmenite composition from the kimberlite rocks of different phases of intrusion are observed. In this case, the rocks of later phases (less deep ones) contain ilme-

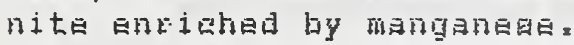

The sequence of crystallization of the mineral of the kimberlite ground mass during the decrease of PT-parameters of the surroundings is established: high magnesian olivine ( Eo) $90 \%$ ) + high titanium chrome spinel $\rightarrow$ magnesian olivine (Eo from 90 to 92 \%) + high magnesian ilmenite $\rightarrow$ chrome containing titanium magnetite $\rightarrow$ perovskite + rutile $\rightarrow$ magnetite.

Ilmenite in the diatremes of the Arkhangelsk diamond bearing province is spread only in the two out of, five fields in its eastern border. The diamond bearing of these kimberlite bodies is rather poor. The pipes are characterized by the high content of ilmenite nodules at the non-considerable presence of the chrome spinels grains.Xenoliths of ilmenite ultrabasites also occur. The size of the ilmenite nodules is usually less than $5 \mathrm{~mm}$, i.e. considerably less than the size of ilmenite nodules inthe Jakutian and South African kimberlites (to $10 \mathrm{~cm}$ ). The impurities of aluminium (less than 0.7 wt. $8 \mathrm{Al}_{2} \mathrm{O}$ ), chromium (to 7 wt.o $\mathrm{Cr}=\mathrm{O}$. , manganese (to 0.5 wt.o MnO) are characteristic of ilmenite. In a whole, the increased content of magnesian (from 10 to 17 wt. 8 Mgo, in average - 13 wt. $f$ ) and decreased - of the

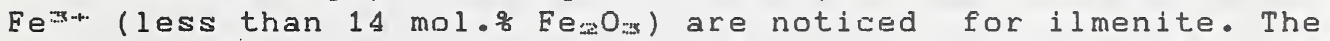
ilmenite composition in general is stable, independing on the diatreme location and it is located on the diagrams in the coordinates $\mathrm{MgTiO}_{3}-\mathrm{EeTiO}_{3}-\mathrm{Fe}_{2} \mathrm{O}_{3}$ and $\mathrm{MnO}-\mathrm{Al}^{2} \mathrm{O}=\mathrm{Cr}=\mathrm{O}=$ in the same field. It is close to the ilmenite composition from the pipes of Daldino-Alakitski and more nothern fields of the Jakutian kimberlite province.

Among xenoliths of the deep rocks in the Arkhangelsk diatremes, only ilmenite therzolites with orange-red low chrome and ferrous garnets are discovered and it shows the genetic affinity of the ilmenite nodules mainly to these rocks. The grains of ilmenite of the eclogite paragenesis occur very seldom and they are characterized by low magnesian content ( less than 3.0 wt.o $\mathrm{MgO}$ ), chromium (less than 0.01 wt. $f$ Cr $=0$ s and are typical for xenoliths of magnesian-ferrous eclogites. Thus, in the Arkhangelsk diamond bearing province, the diatremes with extreme ilmenite specialization and extremely low diamond bearing poor represented mineral-satelites of diamond, and xenoliths of the magnesian series of ultrabasic rocks, occur.

It shuuld be noted, that ilmenite in the kimberlite cement occur in the same diatremes, though it is not the most abundant mineral. Low magnesianity (less than 1 wt.o MgO), increased manganeseanity ( $1-5$ wt.o MnO), low aluminium content (less than 0.6 wt. $\%$ Al. $\mathrm{O}_{\mathrm{s}}$ ) and chromium ( less than 0.8 wt. 8 $\mathrm{Cr}_{2} \mathrm{O}_{3}$ ) are characteristic for 1 lmenite.

In general, ilmenite is similar to the minèral from the non-productive ptpes of the nothern fields of the Jakutian province.

The following sequence of crystallization of minerals of the kimberlite ground mass from the Arkhangelsk province is established: Al-Ti-containing chrome spinel $\rightarrow$ chrome ulvospinel $\rightarrow$ rutile $\rightarrow$ ilmenite $\rightarrow$ titanomagnetite.

Thus, the definite mineralogical and geochemical specialization of the two biggest diamond bearing provinces of the USSR, showing completely different conditions of the evolution not only of the minerals of magnestan-ferrous series of the mantle rock, but also kimberlite melts, is observed. 